\title{
KONTRIBUSI SIKAP SOSIAL DAN MINAT BELAJAR TERHADAP HASIL BELAJAR PKN SISWA SMP KELAS VIII SMP NEGERI 1 MELAYA, KECAMATAN MELAYA KABUPATEN JEMBRANA TAHUN PELAJARAN 2013/2014
}

\author{
Putu Yeni Sagita ${ }^{1}$, Sukadi ${ }^{1}$, \\ I Wyn Landrawan ${ }^{2}$ \\ 1,1,2 Jurusan PPKn \\ Universitas Pendidikan Ganesha \\ Singaraja, Indonesia \\ e-mail: \{yenigita cute@yahoo.com, sukadi@pasca.undiksha.ac.id, landra one@yahoo.co.id
}

\section{ABSTRAK}

Penelitian ini bertujuan untuk mengetahui (1) kontribusi sikap sosial dan minat belajar terhadap hasil belajar PKn (2) kontribusi sikap sosial terhadap hasil belajar PKn (3) kontribusi minat belajar terhadap hasil belajar PKn siswa kelas VIII SMP 1 melaya tahun pelajaran 2013/2014. Penelitian ini adalah penelitian ex post-facto yang menggunakan kuesioner dan hasil belajar siswa. Populasi dalam penelitian adalah siswa kelas VIII SMP 1 melaya tahun pelajaran 2013/2014 sebanyak 240 dengan jumlah sampelnya sebanyak 173 siswa yang diperoleh secara tes proposional random sampling. Data di ambil dengan menggunakan koesioner dan hasil belajar siswa. Analisis data menggunakan teknik analisis dekriptif yaitu analisis regresi ganda dan analisis regresi parsial. Hasil penelitian menunjukkan bahwa (1)Secara bersama-sama dari kontribusi yang signifikan antara sikap sosial dan minat belajar terhadap hasil belajar siswa. (2) terdapat kontribusi yang signifikan dari sikap sosial terhadap hasil belajar siswa. (3) Terdapat kontribusi yang signifikan dari minat belajar terhadap hasil belajar siswa.

Kata kunci: sikap sosial, minat belajar, hasil belajar PKn.

\begin{abstract}
This study aimed to determine (1)the contribution of social attitudes and interest in learning on learning outcomes Civics (2) the contribution of social attitudes towards learning outcomes Civics (3) the contribution interest in learning on learning outcomes Civics eighth grade students of SMP 1 Melaya academic year 2013/2014. This study is an ex post facto research that uses questionnaires and student learning outcomes. The population is the eighth grade students of SMP 1 Melaya academic year 2013/2014 with a sample size of 240, 173 students obtained a proportional random sampling tests. Data taken using koesioner and student learning outcomes. Data analysis using descriptive analysis techniques namely multiple regression analysis and partial regression analysis. The results showed that (1) Put together a significant contribution between social attitudes and interest in learning on student learning outcomes.(2) there is a significant contribution of social attitudes toward student learning outcomes. (3) There is a significant contribution of interest in learning to student learning outcomes.
\end{abstract}

Keywords: social attitudes, interest in learning, learning outcomes Civics. 


\section{PENDAHULUAN}

Dilihat dari tujuan pendidikan nasional, sesuai dengan pasal 3 UU. No. 20 Tahun 2003, yaitu berfungsi mengembangkan kemampuan dan membentuk watak serta peradaban bangsa yang bermartabat dalam rangka mencerdaskan kehidupan bangsa, bertujuan untuk berkembangnya potensi peserta didik agar menjadi manusia yang beriman dan bertaqwa kepada Tuhan Yang Maha Esa, berhaklak mulia, sehat, berilmu, cakap, kreatif, mandiri dan menjadi warga negara yang demokratis dan bertanggung jawab, maka sekolah memegang peranan yang sangat penting dalam proses pendidikan anak karena dalam rangka pendidikan, sekolah sangat besar pengaruhnya terhadap perkembangan jiwa anak terutama sikap sosialnya. Dalam kaitan dengan fungsi pendidikan ini peran sekolah pada hakekatnya tidak jauh dari peran keluarga, yaitu sebagai rujukan dan tempat perlindungan jika anak didik mengalami suatu permasalahan.

Sudah banyak teori, metode, pendekatan, teknik yang telah dilakukan guru untuk meningkatkan hasi belajar PKn siswa, namun hampir semua itu cenderung hanya terfokus pada guru. Hanya sedikit yang menyentuh, kemampuan belajar siswa secara khusus. Meningkatkan hasil belajar siswa jika hanya terfokus pada subjek dalam hal ini guru mengajar dan hanya sedikit yang memperhatikan objek yaitu siswa yang belajar maka hasilnya belum oktimal. PKn di sekolah haruslah memperhatikan tingkat perkembangan peserta didik, kebutuhan peserta didik, sikap peseta didik terutama sikap sosial peserta didik dan keterbatasan waktu secara kurikuler (Lasmawan, 2010). Dengan memperhatikan hal tersebut, hasil belajar PKn dapat ditingkatkan secara oktimal.

Setelah siswa memperoleh pengetahuan, pengalaman di sekolah dalam proses pembelajaran, maka akan terjadi perubahan tingkah laku baik pada aspek kognitif (pengetahuan), afektif (sikap), dan psikomotor (keterampilan) yang merupakan ciri-ciri hasil belajar yang diperoleh siswa (Darmyati dan Mudjono,1999).

Tujuan dari PKn adalah untuk mengembangkan kemampuan berpikir, sikap, dan nilai peserta didik, baik secara individu maupun sosial (Lasmawan, 2010:124). Untuk mendukung tercapainya tujuan pembelajaran atau kompotensi itu, maka pembelajaran berpijak pada pendekatan yang dapat melibatkan siswa secara aktif dalam perolehan makna melalui pengalaman langsung, dalam suasana belajar yang aman dan menyenangkan. Dampak yang diharapkan dari pembelajaran itu adalah terbentuknya siswa sebagai masyarakat pelajar yang kritis dan kreatif, yang mau dan mampu belajar sepanjang hayat. Di samping itu pembelajaran didukung oleh sumber dan media pembelajaran yang dapat membangun prakarsa dan memicu kreativitas siswa. Siswa diberi kesempatan untuk aktif dan mendiskusikan dalam kelompok, berbagai informasi sehingga pengetahuan yang dperoleh siswa dapat bertahan lebih lama, disamping mengupayakan pembentukan sikap siswa dalam berinteraksi dengan lingkungan termasuk terhadap tenaga pengajar, stap administrasi, pegawai perpustakaan dan temannya. Sikap dan nilainilai dalam kehidupan sosial perlu ditanamkan untuk ikut menertai ranah kognitif. Jadi proses pembelajaran yang diungkap di atas dapat meningkatkan hasil belajar siswa.

"Untuk menentukan berhasil atau gagalnya seseorang siswa dalam belajar pada suatu lembaga pendidikan, secara umum digunakan tolak ukur hasil belajar. Hal ini disebabkan oleh hasil belajar merupakan salah satu indikasi tentang hasil pendidikan. Hasil belajar seseorang individu merupakan interaksi antar berbagai yang mempengaruhinya, yang secara umum dikelompokan menjadi dua faktor besar yaitu faktor dalam dan faktor luar" (Sardiman, 2005: 39).

Yang termasuk faktor dalam antara lain kesehatan jasmani, bakat, intelegensi, 
motivasi sikap dan sebagainya. Sedangkan yang termasuk faktor luar di antaranya meliputi kelengkapan sarana prasarana, waktu, kondisi belajar, sumber belajar serta situasi lingkungan dan sebagainya.

Seorang siswa akan dapat belajar dengan baik dan mencapai hasil belajar yang baik pula, apabila didukung oleh faktor dalam (psikologis), seperti sikap dan minat belajar. Sikap adalah kesadaran individu yang menentukan perbuatan yang nyata dalam kegiatan-kegiatan sosial. Maka sikap sosial adalah kesadaran individu yang menentukan perbuatan yang nyata, yang berulang-ulang terhadap objek sosial. Misalnya sikap menerima mata pelajaran $\mathrm{PKn}$ yang diajarkan, sikap saling menghargai teman, sikap tidak membeda-bedakan status sosial dan sikap saling mementingkan kebutuhan bersama. Minat belajar merupakan keterlibatan sepenuhnya seseorang siswa dengan segenap kegiatan pikiran secara penuh perhatian untuk memperoleh pengetahuan dan mencapai pemahaman tentang pengetahuan sosial yang dituntut di sekolah. Minat besar pengaruhnya terhadap aktivitas belajar. Siswa yang berminta terhadap PKn akan mempelajari PKn dengan sungguh-sungguh seperti rajin belajar, merasa senang mengikuti penyajian pelajaran PKn, dan menerapkan sikap sosial di lingkungan keluarga, sekolah dan masyarakat dengan baik.

Sikap sosial dan minat belajar akan senantiasa memberikan landasan dan kemudahan dalam upaya mencapai tujuan belajar secara optimal. Sebaliknya tanpa kehadiran faktor-faktor psikologis seperti sikap sosial dan minat belajar, bisa jadi memperlambat proses belajar, bahkan dapat pula menambah kesulitan dalam mengajar. Sikap sosial dan minat belajar siswa memiliki peranan penting, dapat dipandang sebagai cara-cara berfungsinya pikiran siswa dalam hubungannya dengan pemahaman bahan pelajaran, sehingga penguasaan terhadap bahan yang disajikan lebih mudah dan efektif. Dengan demikian, proses belajar itu akan berhasil baik, kalau didukung oleh faktorfaktor psikologis si pelajar.

Dari hasil observasi tersebut dapat dilihat adanya permasalahan dalam sikap dan minat belajar siswa. Melihat kenyataan di atas sudah tentu akan ada perbedaan hasil belajar antara siswa yang memiliki sikap sosial dan minat belajar PKn yang tinggi dengan siswa lainnya. Oleh karena itu peneliti akan melakukan penelitian tentang "Kontribusi Sikap Sosial dan Minat Belajar terhadap Hasil Belajar PKn Siswa SMP Kelas VIII Negeri Melaya, Kecamatan Melaya Kabupaten Jembrana tahun Pelajaran 2013/2014".

Sikap sosial merupakan kecendrungan potensi atau kesediaan prilaku, apabila individu berdasarkan keyakinanya terhadap objek-objek sikap atau stimulus yang diterimanya. sikap sosial menyebabkan terjadinya tingkah laku yang khas dan berulang-ulang terhadap objek sosial, dan oleh karena itu maka sikap sosial turut merupakan suatu faktor pegerak di dalam pribadi individu untuk bertingkah laku secara tertentu, sehingga sikap sosial dan sikap pada umumnya itu mempunyai sifat-sifat dinamis yang sama seperti sifat motif dan motivasi. Yaitu merupakan salah satu pergerak intern di dalam pribadi orang yang mendorongnya berbuat sesuatu dengan cara tertentu. Sedangkan minat adalah gejala psikologis yang menunjukan bahwa minat adanya pengertian subyek terhadap obyek yang menjadi sasaran karena obyek tersebut menarik perhatian dan menimbulkan perasaan senang sehingga cenderung kepada obyek tersebut. Sedangkan minat belajar adalah suatu rasa lebih suka atau ketertarikan terhadap suatu hal.

\section{METODE PENELITIAN}

Penelitian ex post facto merupakan penelitian yang bertujuan menemukan penyebab yang memungkinkan perubahan perilaku, gejala atau fenomena yang disebabkan oleh suatu peristiwa, perilaku atau hal-hal yang menyebabkan perubahan pada variable bebas yang secara keseluruhan sudah terjadi. 
Lokasi penelitian adalah tempat yang diinginkan dalam melakukan penelitian untuk memperoleh data yang diinginkan. Penelitian ini bertempat di kelas XIII SMP Negeri 1 Melaya tahun ajaran 2013/2014.

Subyek Penelitian adalah siswa- siswi kelas XIII SMP Negeri 1 Melaya tahun ajaran 2013/2014 yang berjumlah 173 siswa, yang terdiri dari 89 siswa laki-laki dan 84 siswa perempuan.

Metode pengumpulan data yang dilakukan dalam penelitian ini adalah dengan memberikan angket pada siswa yaitu angket atau koesioner yang telah diuji validitas dan reliabilitasnya untuk mengetahui sikap sosial dan minat belajar siswa. Pengumpulan data dilakukan dengan mengumpulkan data hasil belajar PKn siswa dengan menggunakan studi dokumentasi.

Penelitian ini menggunakan dua jenis instrumen yaitu kuisioner sikap sosial dan tes hasil belajar.

1. Peneliti menggunakan instrumen berbentuk kuisioner untuk mencari data mengenai sikap sosial dan minat belajar siswa terhadap penerapan pelajaran PKn. Kuisioner ini terdiri dari 30 item pertanyaan yang hasilnya menggunakan skala Likert dengan rentang skor 1-5.

2. Data hasil belajar siswa dikumpulkan dengan menggunakan study dokumentasi yaitu hasil ulangan umum semester ganjil tahun pelajaran 2013/2014.

\section{HASIL PENELITIAN}

Teknik analisis data yang digunakan dalam penelitian ini adalah teknik analisis statistic deskripsi. Deskripsi umum hasil penelitian memaparkan rata-rata, mean, range, skorminimum, skor maximum, standat deviasi, dan varian dari data sikap sosial, minat belajar dengan hasil belajar PKn. Analisis data ini menggunakan program SPSS 16.0 for window.
Dalam analisis data sikap sosial menunjukkan bahwa siswa yang berjumlah 42 orang, jika dilihat dari persentase menjadi $24,3 \%$, data tersebut menunjukkan bahwa sikap sosial siswa tersebut kurang. Siswa yang berjumlah 83 orang, jika dilihat dari persentase menjadi $48,0 \%$, data tersebut menunjukkan bahwa sikap sosial siswa tersebut cukup. Selanjutnya siswa yang berjumlah 45 orang, jika dilihat dari persentase menjadi $26,0 \%$, data tersebut menunjukkan bahwa sikap sosial siswa tersebut tinggi. Sedangkan siswa yang berjumlah 3 orang, jika dilihat dari persentase menjadi $1,7 \%$, data tersebut menunjukkan bahwa sikap sosial siswa tersebut sangat tinggi.

Analisis data minat belajar menunjukkan bahwa siswa yang berjumlah 2 orang, jika dilihat dari persentase menjadi $1,2 \%$, data itu menunjukkan bahwa minat belajar siswa tersebut kurang. Jumlah siswa yang 96 orang, jika dilihat dari persentase menjadi $55,5 \%$, data tersebut menunjukkan bahwa minat belajar siswa tersebut cukup. Selanjutnya siswa yang berjumlah 74 orang, jika dilihat dari persentase menjadi $42,8 \%$, data tersebut menunjukkan bahwa minat belajar siswa tersebut tinggi. Sedangkan siswa yang berjumlah 1 orang, jika dilihat dari persentase menjadi $0,6 \%$, data tersebut menunjukkan bahwa minat belajar siswa tersebut sangat tinggi.

Analisis hasil belajar menunjukkan siswa yang berjumlah 23 orang, jika dilihat dari persentase menjadi $13,5 \%$, data tersebut menunjukkan bahwa hasil belajar siswa tersebut cukup. Selanjutnya siswa yang berjumlah 91 orang, jika dilihat dari persentase menjadi $52,6 \%$, data tersebut menunjukkan bahwa hasil belajar siswa tersebut tinggi. Sedangkan siswa yang berjumlah 59 orang, jika dilihat dari persentase menjadi $34,1 \%$, data tersebut menunjukkan bahwa hasil belajar siswa tersebut sangat tinggi.

Dalam penelitian ini terdapat uji prasyarat analisis. Sebelum dilakukan pengujian hipotesis dengan analisis regresi ganda dan regesi parsial, terlebih dahulu melakukan 
pengujian terhadap prasyarat-prasyarat yang diperolehkan sebelum bisa melanjutkan uji hipotesis. Uji prasyarat analissi meliputi tiga hal yaitu uji normalitas, uji lineritas, dan multikolinearitas.

Uji normalitas dilakukan masing-masing variabel, tujuan analisis normalitas data ini untuk mengetahui data yang akan dianalisis berdistribusi normal atau tidak. Uji normalitas yang digunakan adalah teknik KolmogrovSmirnov. Analisis data ini menggunakan SPSS 16.0 for window.

Hasil Uji Normalitas Sikap Sosial berdasarkan hasil perhitungan yang dilakukan didapatkan pada tabel kerja diperoleh $\mathrm{D}_{\text {hitung }}=$ 0,219 , kemudian hasil yang didapatkan dari perhitungan tersebut di bandingkan dengan $D_{\text {tabel, }}$ dengan $\mathrm{N}=173$ dan taraf signifikansi 0,05 adalah 0,114 . Ternyata $D_{\text {hitung }}$ lebih kecil dari $D_{\text {tabel }}$ sehingga dapat disimpulkan bahwa sampel yang berasal dari populasi untuk data sikap sosial berdistribusi secara normal.

Hasil Uji Normalitas Minat Belajar berdasarkan hasil perhitungan yang telah dilakukan dengan teknik Kolmogrov-Smirnov . di dapatkan hasil pada tabel kerja, diperoleh $D_{\text {hitung }}=0,569$, yang kemudian hasilnya di bandingkan dengan $\mathrm{D}_{\text {tabel, }}$ dengan $\mathrm{N}=173$ dan taraf signifikansi 0,05 adalah 0,144.

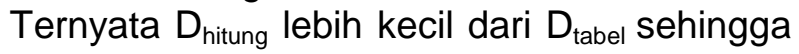
dapat disimpulkan bahwa sampel yang berasal dari populasi untuk data minat belajar berdistribusi secara normal.

Hasil Uji Normalitas Hasil Belajar PKn berdasarkan perhitungan yang telah dilakukan pada tabel kerja diperoleh $D_{\text {hitung }}=$ 0,032 , kemudian hasilnya dibandingkan dengan $D_{\text {tabel, }}$ dengan $\mathrm{N}=173$ dan taraf signifikansi 0,05 adalah 0,144 . Ternyata $D_{\text {hitung }}$ lebih kecil dari $D_{\text {tabel }}$ sehingga dapat disimpulkan bahwa sampel yang berasal dari populasi untuk data hasil belajar berdistribusi tidak secara normal.

Dalam uji linieritas dilakukan untuk mengetahui hubungan antara masing-masing variabel bebas dengan variabel terikat yang terdiri dari variabel bebas yaitu sikap sosial (X1) dan minat belajar (X2) dan variabel terikat yaitu hasil belajar $(\mathrm{Y})$.

Linearitas Antara Variabel Sikap Sosial dan Hasil Belajar dalam hasil analisis menunjukkan ternyata diperoleh $F_{\text {hitung }}$ sebesar 1,428 dengan signifikansi 0,055 . Sesuai kriteria jika signifikansi $F$ hitung lebih besar dari pada signifikansi yang ditetapkan $(0,05)$ maka dapat disimpulkan bahwa data yang berpola linear. Dalam perhitungan ini diperoleh signifikansi $F$ hitung $(0,055)>0,05$ maka data sikap sosial dan hasil belajar PKn berpola linear.

Linearitas Antara Variabel Minat Belajar dan Hasil Belajar dalam hasil analisis menunjukkan ternyata diperoleh $F_{\text {hitung }}$ sebesar 0,769 dengan signifikansi 0,812. Sesuai kriteria jika signifikansi $F$ hitung lebih besar dari pada signifikansi yang ditetapkan $(0,05)$ maka dapat disimpulkan bahwa data yang berpola linear. Dalam perhitungan ini diperoleh signifikansi $F$ hitung $(0,812)>0,05$ maka data minat belajar dan hasil belajar PKn berpola linear.

Uji multikolinearitas digunakan untuk mengetahui apakah terdapat hubungan yang cukup tinggi atau tidak diantara variabelvariabel bebas. Apabila terdapat hubungan yang cukup tinggi (Signifikan) diantara variabel bebas, dapat disimpulkan bahwa terdapat kesamaan aspek yang diukur diantara varibel bebas tersebut. Hal ini berarti tidak layak digunakan untuk menentukan konstribusi secara bersama-sama variabel bebas terhadap variabel terikat. Dalam menganalissi data ini menggunakan SPSS 16.0 for window dan program exsel.

Adapun hasil uji multikolinearitas disajikan pada berikut. Hasil analisis Menghitung koefisien korelasi ganda $\left(\mathrm{R}_{\mathrm{X} 1 . \mathrm{X} 2 . \mathrm{Y}}\right)$.

Tabel Ringkasan Hasil Korelasi

\begin{tabular}{|l|l|}
\hline Simbol Statistik & Nilai Statistik \\
\hline$r_{X 1 . Y}$ & 0,579 \\
\hline$r_{X 2} Y$ & 0,762 \\
\hline$r_{X 1 . X 2}$ & 0,453 \\
\hline \multicolumn{2}{|c|}{ Jika koefisien ganda antar variabel }
\end{tabular}

bebas mendekati koefisien korelasi ganda, maka terjadi multikolinearitas. Berdasarkan perhitungan yang telah dilakukan, diperoleh nilai korelasi ganda $R x_{1} \cdot x_{2 . Y}=0,804$, sedangkan koefisien ganda antar variabel bebas adalah 0,453. Dari hasil tersebut, maka diperoleh bahwa koefisien korelasi ganda antar variabel bebas tidak mendekati 
koefisien korelasi ganda sehingga dapat disimpulkan tidak terjadi multikolinearitas antar variabel bebas. Hal ini berarti layak digunakan untuk menentukan kontribusi secara bersama-sama variabel bebas yaitu sikap sosial dan minat belajar terhadap variabel terikat yaitu hasil belajar.

Uji Hipotesis Regresi Ganda (X1 dan X2 terhadap Y). Bunyi hipotesis yaitu:

$\mathrm{HO}$ : Tidak terdapat kontribusi ysng signifikan antara sikap sosial dan minat belajar siswaterhadap hasil belajar PKn siswa kelas VIII SMP 1 Melaya Tahun Pelajaran 2013/2014.

Ha: Terdapat kontribusi yang signifikan dari sikap sosial dan minat belajar siswa terhadap hasil belajar PKn siswa kelas VIII SMP 1 Melaya Tahun Pelajaran 2013/2014.

Uji hipotesis 3 dilakukan dengan teknik regresi ganda. Dalam analisis data menggunakan SPSS 16.0 for window.

Pengujian hipotesis :

Untuk menguji penelitian, secara statistik dilakukan melalui langkah-langkah berikut,

1. Lihat nilai $R$ (koefisien korelasi ganda) gunanya untuk mengetahui keeratan hubungan antara variabel $\mathrm{X} 1$ dan $\mathrm{X} 2$ terhadap variabel terikat $Y$. Hasil analisis menunjukkan nilai $R=0,806$, hal ini menunjukkan bahwa terdapat hubungan yang lemah sikap sosial (X1) dan minat belajar (X2) terhadap hasil belajar $(Y)$.

2. Lihat nilai $F$ statistik (biasanya disebut uji F) dan nilai signifikan.

Nilai F statistik dapat digunakan untuk mengetahui tingkat signifikan kontribusi variabel bebas terhadap variabel terikat. Apakah pengaruh nyata atau bermakna. Dengan membandingkan nilai $F$ statistik dengan nilai $F$ tabel dapat diketahui tingkat signifikannya. Kita lihat dari tabel ANOVA bahwa nilai $F$ statistik sebesar 157,104 sedangkan $F$ tabel dengan signifikan 0,05 diperoleh nilai F sebesar 3,11. Jika dibandingkan antara $F$ statistik atau $F$ hitung dengan $F$ tabel maka $157,104>3,11$, jadi keputusannya menerima hipotesis yang menyetakan bahwa terdapat kontibusi yang signifikan antara sikap sosial (X1) dan minat belajar (X2) terhadap hasil belajar PKn (Y). Hasil analisis menunjukkan harga konstanta besarnya 0,655 ; harga koefisien $\mathrm{X} 1$ besarnya 0,279 dan X2 besarnya 0,853 . Semua koefisien tersebut signifikan karena signifikannya 0,000. Jadi persamaan garis regresinya adalah $Y=0,297 \times 1+0,853 X 2+0,655$.

Ternyata $F_{\text {hitung }}>F_{\text {tabel }}$ atau 157,104 lebih besar daripada 3,11, sehingga nilai $F_{\text {hitung }}$ signifikan. Dengan demikian maka Ho ditolak dan Ha diterima. Jadi dapat disimpulkan bahwa terdapat hubungan yang signifikan antara sikap sosial dan minat belajar siswa terhadap hasil belajar PKn siswa kelas VIII SMP 1 Melaya Tahun Pelajaran 2013/2014.

Selanjutnya untuk mengetahui seberapa besar sumbangan variabel sikap sosial dan minat belajar terhadap hasil belajar dapat ditentukan dengan rumus koefisien determinan sebagai berikut.

Berdasarkan perhitungan dapat disimpulkan bahwa terdapat kontribusis yang signifikan sikap sosial dan minat belajar terhadap hasil belajar PKn siswa kelas VIII semester ganjil SMP N 1 Melaya di Kecamatan Melaya Kabupaten Jembrana tahun ajaran 2013/2014. Jadi kontribusi secara bersama-sama sikap sosial dan minat belajar terhadap hasil belajar adalah $64,50 \%$.

Uji Hipotesis Regresi Parsial (X1 dengan Y). Hipotesis berbunyi : Terdapat hubungan yang signifikan antara sikap sosial siswa terhadap hasil belajarPKn siswa kelas VIII SMP 1 Melaya Tahun Pelajaran 2013/2014. Uji hipotesis pertama dilakukan dengan teknik regresi parsial yang kemudian dilanjutkan dengan perhitungan product moment. Dalam analisis data ini menggunakan SPPS 16.0 for window. Selanjutnya untuk mengetahui sumbangan kontribusi hubungan antara variabel sikap 
sosial dan hasil belajar digunakan perhitungan rumus koefisen determinan.

Berdasarkan perhitungan dapat disimpulkan bahwa terdapat kontribusis yang signifikan sikap sosial terhadap hasil belajar PKn siswa kelas VIII semester ganjil SMP N 1 Melaya di Kecamatan Melaya Kabupaten Jembrana tahun ajaran 2013/2014. Jadi kontribusi secara bersama-sama sikap sosial dan minat belajar terhadap hasil belajar adalah $20,61 \%$.

Uji Hipotesis Regresi Parsial (X2 dengan Y). Hipotesis berbunyi : Terdapat hubungan yang signifikan antara minat belajar siswa terhadap hasil belajar PKn siswa kelas VIII SMP 1 Melaya Tahun Pelajaran 2013/2014. Uji hipotesis kedua dilakukan dengan teknik regresi parsial yang kemudian dilanjutkan dengan perhitungan product moment.. Selanjutnya untuk mengetahui sumbangan kontribusi hubungan antara variabel minat belajar dan hasil belajar diguankan perhitungan rumus koefisen determinan.

Berdasarkan perhitungan dapat disimpulkan bahwa terdapat kontribusis yang signifikan minat belajar terhadap hasil belajar PKn siswa kelas VIII semester ganjil SMP N 1 Melaya di Kecamatan Melaya Kabupaten Jembrana tahun ajaran 2013/2014. Jadi kontribusi secara bersama-sama sikap sosial dan minat belajar terhadap hasil belajar adalah $43,88 \%$.

\section{PEMBAHASAN}

Berdasarkan hasil analisis data diperoleh bahwa ketiga hipotesis yang diajukan yaitu: Hipotesis I berbunyi : Terdapat hubungan yang signifikan antara sikap sosial siswa terhadap hasil belajar PKn siswa kelas VIII SMP 1 Melaya Tahun Pelajaran 2013/2014, Hipotesis II berbunyi : Terdapat hubungan yang signifikan antara minat belajar siswa terhadap hasil belajar PKn siswa kelas VIII SMP 1 Melaya Tahun Pelajaran 2013/2014, Bunyi hipotesis III yaitu: Terdapat hubungan yang signifikan antara sikap sosial dan minat belajar siswa terhadap hasil belajar PKn siswa kelas VIII SMP 1 Melaya Tahun Pelajaran 2013/2014, diterima.

Dari hasil analisis regresi diketahui bahwa terdapat hubungan yang signifikan antara sikap sosial terhadap hasil belajar. Dalam hasil penelitian ini diperoleh bahwa sikap sosial berkontribusi sebesar 20,61\% terhadap hasil belajar PKn siswa kelas VIII SMP 1 Melaya Tahun Pelajaran 2013/2014.

Menurut Hasnanis sikap adalah kesadaran individu yang menentukan perbuatan yang nyata dalam kegiatankegiatan sosial. Maka sikap sosial adalah kesadaran individu yang menentukan perbuatan yang nyata, yang berulang-ulang terhadap objek sosial. Hal ini terjadi bukan saja pada orang-orang lain dalam satu masyarakat.

Salah satu faktor yang mempengaruhi hasil belajar adalah minat belajar. Hasil analisis di atas juga diperoleh bahwa minat belajar berkontribusi signifikan terhadap hasil belajar Pkn. Dari hasil analisis tersebut diperoleh bahwa minat belajar berkontribusi sebesar 43,88\% terhadap hasil belajar PKn siswa.

Berdasarkan paparan tentang hubungan sikap sosial dan minat belajar terhadap hasil belajar PKn maka dapat disimpulkan bahwa kedua faktor tersebut memberikan kontribusi yang signifikan terhadap hasil belajar PKn. Hal tersebut dapat diketahui dari besarnya kontribusi kedua faktor terseebut secara bersama-sama adalah 64,50\%. Dengan demikian maka perlu diketahui tingkat sikap sosial dan meningkatkan minat belajar siwa agar hasil belajar siswa sesuai dengan apa yang diharapkan.

Pernyataan di atas sesuai dengan teori yang telah dipaparkan oleh (Gerungan, 2004) Sikap sosial dinyatakan oleh cara-cara kegiatan yang sama dan berulang-ulang terhadap obyek sosial, dan biasanya dinyatakan oleh sekelompok orang atau masyarakat. Minat adalah gejala psikologis yang tidak dibawa sejak lahir, yang 
menunjukan bahwa minat adanya rasa lebih suka subyek terhadap obyek yang menjadi sasaran karena obyek tersebut menarik perhatian dan menimbulkan perasaan senang sehingga cenderung kepada obyek tersebut.

Sehingga berdasarkan paparan tersebut, maka kita dapat memikirkan bagaimana cara mengetahui tingkat sikap sosial dan meningkatkan minat belajar PKn siswa. Cara untuk mengetahui tingkat sikap sosial dan minat belajar siswa bisa dimulai dari cara mengajar guru dengan memperhatikan masing-masing karakter siswa sehingga dapat mengetahui tingkat sikap sosial siswa secara keseluruhan dan seberapa besar minat belajar siswa dalam proses kegiatan pembelajaran di dalam kelas. Guru juga harus bisa menciptakan suasana yang kondusif dan menyenangkan bagi siswa untuk belajar sehingga siswa lebih tertarik untuk belajar. Penilaian yang tidak terlalu terpaku pada nilai ulangan saja juga akan mengurangi kecemasan terutama pada siswa yang kurang pintar.

\section{SIMPULAN DAN SARAN}

Berdasarkan hasil penelitian dan pembahasan dapat dikemukakan simpulan sebagai berikut. (1)Terdapat hubungan yang signifikan antara sikap sosial terhadap hasil belajar PKn siswa kelas VIII SMP 1 Melaya Tahun Pelajaran 2013/2014. (2) Terdapat hubungan yang signifikan antara motivasi belajar terhadap hasil belajar IPA siswa kelas VIII SMP 1 Melaya Tahun Pelajaran 2013/2014. (3) Terdapat hubungan yang signifikan antara sikap sosial dan minat belajar terhadap hasil belajar PKn siswa kelas VIII SMP 1 Melaya Tahun Pelajaran 2013/2014.

Berdasarkan hasil penelitian ini, maka dapat diajukan beberapa saran sebagai berikut.

1. Bagi siswa disarankan untuk selalu mengembangkan sikap sosial dan meningkatkan minat belajar untuk meningkatkan hasil belajar khususnya hasil belajar PKn.
2. Guru hendaknya berusaha untuk mengetahui tingkat sikap sosial dan motivasi belajar siswa untuk meningkatkan hasil belajar siswa khususnya hasil belajar PKn.

3. Bagi lembaga sekolah disarankan agar lebih memperhatikan sikap sosial siswa dan meningkatkan minat belajar siswa secara keseluruhan. Sehingga siswa akan mendapat perlakuan yang lebih dalam proses pembelajaran.

4. Bagi peneliti lain yang berminat terhadap temuan penelitian ini dapat melakukan pembuktian-pembuktian lebih mendalam dengan mengambil populasi dan sampel yang lebih besar.

\section{DAFTAR PUSTAKA}

Dimayanti dan Mudjiono.1999. Belajar dan Pembelajaran. Jakarta: Depdiknas

Gerungan. 1964. Psikologi Sosial. Bandung: ADITAMA

Gerungan. 2004. Psikologi Sosial. Bandung: Refika Aditama

Lasmawan, Wayan. 2010. Menelisik Pendidikan IPS Dalam Perspektif Konstektual-Empiris. Singaraja:Press.

Sardiman. 2005. Interaksi \& Motivasi Belajar Mengajar. Jakarta: RajaGrafindo Persada.

Slameto. 2003. Belajar dan Faktor-Faktor yang Mempengaruhinya. Jakarta: Rineka Cipta.

Sofyan, Nurbaeti. 2004. Skripsi : Hubungan antara Minat dan Perhatian dengan Prestasi Belajar Siswa Mata Pelajaran IPA pada SDN Labuang Baji I Makassar. Makassar: Universitas Veteran Republik Indonesia 